\title{
Solid Waste Management in Africa: A Review
}

Ibrahim Adebayo Bello, Muhamad Norshafiq bin Ismail and Nassereldeen A Kabbashi*

Department of Biotechnology Engineering, International Islamic University Malaysia Gombak, 50728, Malaysia

*Corresponding author: Nassereldeen A Kabbashi, Department of Biotechnology Engineering, International Islamic University Malaysia Gombak, 50728, Malaysia, Tel: +603 6196 4524; E-mail: nasreldin@iium.edu.my

Received date: March 28, 2016; Accepted date: May 07, 2016; Published date: May 14, 2016

Copyright: (c) 2016 Bello IA, et al. This is an open-access article distributed under the terms of the Creative Commons Attribution License, which permits unrestricted use, distribution and reproduction in any medium, provided the original author and source are credited.

\begin{abstract}
As a result of globalization, the quantity and generation rate of solid waste in Africa have increased tremendously and this calls for the need to salvage the situation before it gets out of hand. This article presents the review of solid waste trends in Africa from the pre-colonial era till the present day. It also discusses the composition of solid wastes, collection, transportation and disposal in different African countries. Different types of waste have been generated over the years but the management strategies implemented are inadequate. Waste management in African is faced with numerous challenges and recommendations for improved and efficient solid waste management have been proposed.
\end{abstract}

Keywords: Solid waste management; Africa; Challenges; Recommendations

\section{Introduction}

Globalization is known to affect peoples' consumptions, usage of solid materials that eventually results huge solid wastes. According to Leton and Omotosho [1], solid wastes is defined as non-liquid or nongaseous products (e.g. trash, junk and or refuse) of human activities that are unwanted. Generation of Municipal solid waste (MSW) increases in line with developmental rate of any country. Africa is known to be the least developed region in the world with $38 \%$ urbanization. Although, this is low compared to many other countries in the world, African countries are experiencing rapid development with growth rate of four percent per annum [2]. African countries are now faced with huge amount MSW which has direct effect on the human health, safety and environment.

Budgets granted for managing MSW is 20-50 percent of overall budget but still the collection of the waste is not fully covered. In a study about South Africa's integrated pollution and waste management system, a strategy was suggested to enable South Africa overcome the waste management problem left under the apartheid rule. These strategies were to minimize or totally eradicate waste generation, transportation or movement, adopt new technologies for pollution prevention and efficient use of energy, resources and materials [2].

Besides MSW, there are major types of wastes that contribute to the increase in waste production worldwide. They are Construction and Demolition (C\&D), End-of-life Vehicles (EoLV), Biomass wastes in form of agriculture wastes and forestry wastes, health-care waste and electronic waste (e-waste). Health-care wastes are sometimes considered as a sub-category of hazardous wastes, packaging wastes, and marine litter which consists of discarded material during recreational, fisheries or personal hygiene activities. As mentioned earlier, the wastes generation for a country is dependent upon the population growth and also the income. However, income seems to be the driving factor for wastes generation because countries with high income but of a lower population show a significant amount of waste generation. Amount of the wastes generated and the need for them to be managed is important very. Mixed MSW, medical wastes, industrial wastes and hazardous wastes pose a great threat to the society because they are generally harmful and dangerous to people. Without proper management and landfill facilities, these wastes will not only become a sore in the eyes but will turn into something even more critical, possibly spreading an epidemic.

With the development in electrical and electronic industry, generation of e-waste definitely is a serious problem worldwide with China leading as the biggest generator of e-waste [3] carrying about $64 \%$ of total e-waste generated while countries like India and Brazil generate a large amount of e-waste of about $13 \%$ and $11 \%$ respectively. Countries such as Senegal, Uganda and South Africa are expected to increase the amount of e-waste generated by factor two to eight in the next 10 years [4]. What makes this review spectacular is that it discusses an aspect of waste (e-waste) which wasn't so common in the past.

\section{Types of Wastes}

Municipal solid wastes (MSW) are waste generated every day. They are also simply known as garbage or trash. There are various sources of MSW and it can be deduced that every sector of industries are generators of MSW. All sectors are considered as sources of MWS, however as far as construction and demolition (C\&D) industries are concerned, it is common to manage the waste separately from other MSW given that responsible parties will be in charge of proper management [5]. For residential, these are wastes produced every minute in which the generator is the resident itself and the types of waste usually produced are from daily life activities. The examples of such are paper, tin, bottle, clothes, glass, metals, e-wastes and hazardous wastes such as paint and aerosol spray. Residential wastes are among the highest generator of waste. In Uganda for example, the residential wastes takes a portion of $52-80 \%$ of the weight of wastes produced, followed by markets, commercial sectors, industrial sectors and others. The major wastes produced are the food wastes while minor portion of the wastes produced are comprised of paper, plastics and ceramics. This also happens at other African countries like Kenya. A case study of 4 towns in Kenya; Nairobi, Nakuru, Mombasa and 
Kisumu shows that around $61 \%$ of the wastes produced there are residential wastes, followed by industrial and others such as hospitals and markets [6]. It is a norm for industrial sector to produce a huge amount of wastes which can be from automobile, fabric, manufacturing industries, construction sites or power plants. The wastes produced vary depending on the raw material used. For Africa region, the type of waste generated depends on the country. For example, Egypt, Ethiopia and Botswana focus on textile industry as the manufacturing sub-sector while Nigeria, Senegal and South Africa are examples that prioritize food industry whereas Tunisia is well known for their clothing industry.

In general, African countries involved in industries such as food, textile, furniture, clothing, iron and steels, chemicals, printing and food industry are ranked first in many of African countries. Institutional wastes are wastes generated by institutional sectors such as school while construction and demolition wastes are produced from construction wastes that arise from streets cleaning, park, beach and wastewater treatment sites all fall under the municipal services wastes [7].

There are other classes of wastes that contribute significantly to waste generation around the world. These are process wastes, medical wastes and agricultural wastes. Process wastes are the wastes that are produced during the manufacturing processes e.g. metal scrap materials from manufacturing industries. Wastes from hospitals are called medical wastes. They are very important and require proper management because some of them are considered hazardous.

Wastes from agricultural sector can be used as raw materials for biogas production and to make bio-compost which then can be used as fertilizer for the crops [5]. There is a huge difference waste management between developed and developing countries. Developed countries try to create a complex and high cost system to handle wastes while some of the developing countries still make use of improper handling methods [8].

\section{Trends in Solid Waste Management in Africa}

One of the major problems in urban centres nowadays is the collection, treatment, transportation, storage, and eventual disposal of waste $[9,10]$. Consequently, people have witnessed a relatively poor waste management practices characterized by indiscriminate dumping of refuse in water bodies and isolated places which further exacerbates the already low sanitation level in most African countries. The prevailing increase in the level of urbanization in Africa is expected to continue in the future. However, a major concern is that there are no adequate infrastructural facilities and appropriate land use planning to match up with the demands posed by the urban growth rate especially the slums and ghettos in Africa [11].

History has shown that human existence was peaceful and harmonious as a result of a proper waste management whose effect could be seen in environmental and public health. In the ancient history (10,000 BC to 4,000 AD), the major constituents of waste were wood, food wastes, vegetables etc. Waste at that time was simply domestic and so generally biodegradable. There were no industries and human population was quite small, therefore little wastes were generated. The edible part of the waste was fed to animals while the remaining was allowed to decompose in the ground and there were nothing like waste management systems. Archaeological studies from clay samples have revealed that wastes from different sources in the past formed stratified layers with time.
What was obtainable as at then was that household would spread a clean sheet of fresh clay over littered floor which later gave rise to stratified layers. As the population density increased with time, there was a corresponding increment in the level of waste generation, hence a need for a more viable solution. There was need for a system that would manage waste effectively and efficiently. In history, the Romans were among the first set of people that started a waste management system wherein some collection teams were organized to collect waste generated in the households and streets for disposal at the outskirts of the city [12]. The world population growth rate nowadays is on a geometric progression. As a result of this, there is an increase in consumption rate which brings about a direct effect in the generation of both domestic and industrial waste. Various reports have shown that per capita waste generation increased nearly 3 -folds over the last two decades, bringing it to a level 5-6 times higher than of the developing countries. Waste was not a threat until urban populations began to increase rapidly. Waste began to pile up and when that happened, it resulted into a source of odour, disease breakout (plagues) and contamination of water supply. In the $1340 \mathrm{~s}$, there was a widespread of plagues to Western Europe and northern part of Africa. This phenomenon was termed Black Death. About seventy five million deaths were estimated worldwide and thirty to sixty percent of Europe population was involved. In bid to curbing the incessant spread of diseases, this period happened to be an eye opener to waste management techniques. As a form of reuse and recycling, vegetable wastes were fed to livestock and green waste was used as fertilizer, pigs were fed organic wastes and timbers were reused in construction works. This approach where by materials are reused over and over again is referred to as the cradle to cradle system [13].

The 18th century gave rise to the Industrial Revolution in which the western countries were rapidly developing in areas of trade, skill acquisition, product innovation and machinery development. What assisted in such a rapid development was the availability of raw materials and good number of work force. With time, there came the age of sanitation which was basically to prevent impending problems associated with improper management of disposal sites. Waste collection and disposal at designated sites was in operation. All these were aimed at maintaining the public health and till now, the monthly Environmental Sanitation has remained a practice in most of the African countries such as Nigeria and Tanzania.

With the advent of the modern times (1900), major parts of the developed world such as the United States and Europe have established more sophisticated waste management and landfill programs. Thus, there was introduction of modern technologies and imposition of certain regulations to protect the health and overall well-being of man. Most part of Africa started developing, population rate started increasing and there was need for more production and use of materials to cater for the needs of people, hence an increase in waste generation.

During the colonial era, waste management was efficient because the colonial masters introduced new methods of waste management into Africa. Waste management in developed parts of East Africa gradually became centralized [14], with the introduction of refuse trucks that would collect wastes from points of generation and deposit them at designated sites [15]. During the 1940s to early $1960 \mathrm{~s}$, waste management in Africa was quite efficient because the population growth was still low and there was adequate resources to cater for the teaming population [15]. However, after most of the African countries gained independence, some of them could not handle the legacy left by 
the colonial masters and hence, a total decline in the waste management system. Practices such as waste collection, storage, treatment and final disposal are currently reported to be major problems in urban centres $[9,15,16]$.

\section{Solid Waste Composition}

The major composition of wastes generated in most part of Africa is biodegradable organic materials as shown in Table 1. Most of the waste are biodegradable based on peoples consumption which generates much kitchen and compound wastes [17]. As a result, there is need for an efficient collection system to forestall disease outbreak and other negative environmental impact. Moreover, the global trend of electronic gadgets which ultimately generates e-waste is becoming a threat in Africa [18]. There is therefore the need for efficient system of collection to avoid negative environmental impacts.

\section{Collection and transportation of waste}

There exists three major phases of wastes collection in Africa. These are the informal phase, primary and secondary phase. The informal and primary phases are basically the ones from household to community collection points. The formal institutions such as urban councils and private operators are the ones in charge of the secondary phase. Wastes are usually transported from community transfer points to landfills or final disposal sites. Private operators have also been utilized in waste collection. They collect waste directly from households by door to door approach. This is typical of countries in East African urban centres where waste collection in shopping malls and their environs have been contracted out to the private waste collectors. However, the community market and hospitals still rely on collection arrangements made by the urban council which is a public parastatal. Another style of collection common to African countries is the "summon to bring" system. In this system, the collection truck already has a specific time it comes around on specific days of the week. When it arrives, it hoots its horn to summon the people to bring their waste for disposal. The frequencies at which wastes are thrown is dependent on the classes (levels) of the individuals- low-income and high income classes. The high-income class dispose waste more often than the low income class $[9,14]$. Disposable waste is mainly by manual loading onto the truck by government workers and the volumes of waste collected often vary. The percentage of waste collected vary between thirty five and sixty eight, which is comparable to other urban councils in developing countries [19-21]. Furthermore, the advent of private sector operation in most African countries jerked-up solid waste collection level more than when it was solely dependent on the urban councils $[9,15]$.

In Abuja Nigeria, for instance, there are numerous private waste collection companies in operation. Each one as a specified route and specific time of arrival on a weekly or monthly basis [22]. To a large extent, there has been consistency in waste collection for some neighbourhood while it varies with others. The inconsistencies in other areas is mostly due to shortage of staff, insufficient collection vehicles, rising cost of living, etc. House to house waste collection is carried out with home owners being responsible for placing their waste bins in front of their houses. The waste collector designated to each house takes the waste bin, empties it and then places it back to the frontage of the house [22] (Table 1).

\begin{tabular}{|l|l|l|l|l|l|l|}
\hline Waste Composition (\%) & Dar es Salaam & Moshi & Kampala & Jinja & Lira & Nairobi \\
\hline Bio-waste & 71 & 65 & 77.2 & 78.6 & 68.7 & 65 \\
\hline Paper & 9 & 9 & 8.3 & 8 & 5.5 & 6 \\
\hline Plastic & 9 & 9 & 9.5 & 7.9 & 6.8 & 12 \\
\hline Glass & 4 & 3 & 0.7 & 1.3 & 2 \\
\hline Metal & 3 & 2 & 0.3 & 0.5 & 2.2 & 1 \\
\hline Others & 4 & 12 & 3.4 & 0.35 & 14.9 & 14 \\
\hline Kg/cap/day & 0.4 & 0.9. & 0.59 & 55 & 0.5 & 0.6 \\
\hline Percent collection & 40 & 61 & 60 & 91,153 & 107,809 & $4,000,000$ \\
\hline Population & $3,070,060$ & 183,520 & $1,700,850$ & ND & ND & 45 \\
\hline $\begin{array}{l}\text { Population paying for collection(\% of total } \\
\text { population }\end{array}$ & & 35 & ND & & \\
\hline
\end{tabular}

Table 1: Composition of solid wastes generated in East African urban centres.

Note: $\mathrm{ND}=$ Not determined

Source: + KCC, 2006; \#NEMA 2007.

\section{Solid waste management challenges}

All countries have regulations and policies which dictates how waste should be managed $[15,23,24]$. Responsibilities especially in the areas of health, environmental management and planning expected by law are well spelt out [9]. One major challenge of MSW in Africa is the creation of enough capacity not only limited to monetary terms but also in technological and infrastructural advancement. This is required so as to drive at an environmentally sound waste management wherein recovery and recycling of waste streams across Africa will be achieved. There is need to have access to finance and technical knowledge and this will go a long way in assisting the waste management municipalities who are most times ill-equipped to deal with prompt collection and disposal of waste. Furthermore, private sectors that have 
the means and are willing to go into waste management have been prevented by certain by-laws which gives all waste management responsibilities to government bodies. In addition, lack of transparency, bad governance and prevalence of corruption in most African countries are major problems militating against efficient MSW management. Importation of substandard products and nonoperational laws and policies have also contributed to rapid increase in waste generation.

\section{The Way Forward}

The following are recommendations that could enhance a better solid waste management in African countries.

1. Heads of African countries should seek support from the international community. International communities are known for their knowledge and technical know-how and as such, African countries could sign a bilateral agreement with them on coming to invest in their countries for an environmentally sound management of waste streams in African [5].

2. The people's perception and orientation about waste needs to change. In some African countries, people no longer regard solid waste as harmful. They now see it as opportunities of making money to earn a living [5].

3. Relevant international agreements on waste management and provision of assistance to African countries should be met. Furthermore, summit of all African countries should be put in place if not already in place. This will serve as avenues where pressing and current matters on how to solve waste management problems would be discussed. Laws and policies should also be reinforced and offenders must be brought to book.

4. Private sectors should be actively involved. They should be allowed to partner with government bodies. This will create employment opportunities and more jobs for the teaming population.

\section{References}

1. Leton T, Omotosho O (2004) Landfill operations in the Niger delta region of Nigeria. Eng Geol 73: 171-177.

2. Muzenda E, Belaid M, Mollagee M, Motampane N, Ntuli F (2011) Reflecting on Waste Management Strategies for South Africa. World Congr Eng Comput Sci 2: 19-21.

3. Song Q, Li J (2014) A systematic review of the human body burden of ewaste exposure in China.

4. Modak P (2011) Waste Investing in energy and resource efficiency.

5. Daniel H, Perinaz BT (2012) What a waste - A Global Review of Solid Waste Management.

6. Mwesigye P, Mbogoma J, Nyakango J (2009) Africa review report on waste management Main Report.
7. Nebiyeleul G (2006) African Regional Implementation Review for the Commission on Sustainable Development ( CSD-14 ) Report on the Review of African Sustainable Industrial Development. African Reg Implement Rev Comm Sustain Dev no.

8. Sthiannopkao S, Wong MH (2013) Handling e-waste in developed and developing countries: Initiatives, practices, and consequences. Sci Total Environ 463: 1147-1153.

9. Kaseva M, Mbuligwe S (2005) Appraisal of solid waste collection following private sector involvement in Dar es Salaam city, Tanzania. Habitat Int 29: 353-366.

10. Okot-Okumu J (2012) Solid Waste Management in African Cities-East Africa.

11. Pichtel J (2005) Waste management practices: municipal, hazardous, and industrial.

12. Cleary J (2009) Life cycle assessments of municipal solid waste management systems: a comparative analysis of selected peer-reviewed literature. Environ Int 35: 1256-1266.

13. Liyala C (2011) Modernising solid waste management at municipal level: institutional arrangements in urban centres of East Africa.

14. Okot-Okumu J, Nyenje R (2011) Municipal solid waste management under decentralisation in Uganda. Habitat Int 35: 537-543.

15. Mgimba C, Sanga A (2016) Municipal Solid Waste Composition Characterization for Sustainable Management Systems in Mbeya City, Tanzania. International Journal of Science, Environment and Technology 5: 47-58.

16. Ojok J, Koech MK, Tole M, Okot-Okumu J (2014) Households Perception, Attitudes and Expectations on Solid Waste Management in Kampala, Uganda. The Journal of Solid Waste Technology and Management 40: 335-348.

17. Schluep M, Wasswa J (2008) e-Waste assessment in Uganda: A situational analysis of e-waste management and generation with special emphasis on personal computers. Kampala Uganda Clean Prod Cent.

18. Palczynski R (2002) Study on solid waste management options for Africa. Proj Rep African Dev Bank.

19. Supriyadi S, Kriwoken L, Birley I (2000) Solid waste management solutions for Semarang, Indonesia. Waste Management \& Research 18: 557-566.

20. Vidanaarachchi C, Yuen S, Pilapitiya S (2006) Municipal solid waste management in the Southern Province of Sri Lanka: Problems, issues and challenges. Waste Manag 26: 920-930.

21. Kadafa A, Manaf L, Sulaiman W (2014) Applications of system analysis techniques in Solid Waste Management assessment. Polish Journal of Environmental Studies pp: 1061-1070.

22. Liyala C (2011) Modernising solid waste management at municipal level: institutional arrangements in urban centres of East Africa.

23. Tukahirwa J (2011) Civil society in urban sanitation and solid waste management: The role of NGOs and CBOs in metropolises of East Africa.

24. Wilson D, Velis C, Cheeseman C (2006) Role of informal sector recycling in waste management in developing countries. Habitat Int 30: 797-808. 